\title{
Collaboration patterns and product innovation in the Basque Country. Does a firm's nationality matter?
}

\author{
Henar Alcalde Heras ${ }^{1}$
}

\begin{abstract}
More and more, the ability to innovate can be considered as an explanatory factor in determining the long-term potential of firms to be competitive. Therefore, it is of increasing importance to understand the critical success factors behind notably radical product innovations. The present paper explores the yields and results in terms of a series of competitiveness indicators that domestic and foreign firms in the Basque Country obtain from technological collaboration practices. In particular, the study seeks to assess differences in the way these two groups of firms organize their technological partnerships (in terms of the geographical spread of partners with whom they cooperate and the purposes for which they deploy collaboration: for commercial or science/knowledge generation), and the comparative differences that stem from their respective practices. The study uses firm level data from the Euskadi Innovation Survey 2011, for firms located in the Basque Country. The paper finds that (a) technological collaborations comprising different types of partners have the greatest positive impact on innovation novelty, and (b) when looking at the firm's nationality, collaboration strategies developed by foreign firms have a higher impact on achieving novel innovation. We posit that the higher degree of product innovation we observe among foreign firms - as opposed to domestic firms in the Basque Country - relies on their ability to benefit from both inter-regional partnerships and commercial-based networks for the sake of innovation purposes.
\end{abstract}

Keywords: collaboration, product novelty, ownership nationality, innovation

\section{Introduction}

This research explores the yields and competitiveness that domesticowned and foreign-owned firms located in the Basque Country obtain from collaboration practices. Specifically, this research tries to determine whether a firm's nationality (foreign versus local knowledge base) moderates the

1 Henar Alcalde Heras, Dr, Researcher, Orkestra-Basque Institute of Competitiveness and Deusto Business School C/ Mundaiz, 50 20012, Donostia-San Sebastián Spain, tel: +34 943297 327, fax: +34 943279 323, henar.alcalde@orkestra. deusto.es. 
impact of technological collaboration agreements on that firm's ability to bring novel products.

Literature has largely shown that collaboration is a good method of improving firms' innovation capabilities. When relevant resources are not available in the organization itself, technological collaboration offers a good solution for product innovations. As long as innovation complexity increases, firms' ability to identify and absorb relevant knowledge will support the development of new products. (Becker and Dietz, 2004; Belderbos, Carree, Diederen, Lokshin and Veugelers, 2004; Nieto and Santamaria, 2007).

The rationale behind the research follows on from an analysis of innovation and competitiveness indicators with regard to domestic-owned companies from the Basque Country (CAPV). These companies can be considered highly competitive according to their levels of innovative performance in the national market. However, their position is far below average when comparisons are made with foreign-owned companies located inside the CAPV. For example, in 2010 the percentage of domestic-owned firms that introduced a novel product in the market was $8.8 \%$, while the average was $20.89 \%$ for foreign-owned firms located inside the CAPV. However, when we look at firms engaged in technological collaboration we find that $45.71 \%$ of domestic-owned companies has developed technological collaboration; this figure is very similar to the $42.3 \%$ of foreign-owned firms (located inside the CAPV) engaged in technological partnerships.

Therefore, previous figures suggest that domestic-owned firms in the Basque Country do not perform efficient innovation practices, and their underperformance can be a consequence of unsuitable collaboration practices. In order to build a competitive innovation strategy, this research will explore what would be suitable collaboration patterns for firms located in the CAPV to achieve novel product innovations. Specifically, as explained in Figure 1, we assess whether the nature of the knowledge base (defined by a firm's nationality) moderates the impact of technological collaboration agreements on the degree of product newness. We focus on product characteristics to determine whether an innovation can be considered radical or incremental. Radical innovations describe innovations with a higher degree of novelty, new or significantly improved products that involve a novelty for the market in which the firm operates. On the other hand, incremental innovations describe incremental product innovations without modifications or with slight modifications.

The paper proceeds as follows. The next section discusses different collaboration patterns, and sets out the hypotheses. Section 3 discusses the methodology and data; Section 4 presents the results; and the final section presents the conclusions. 
Figure 1. Model specification for hypotheses development

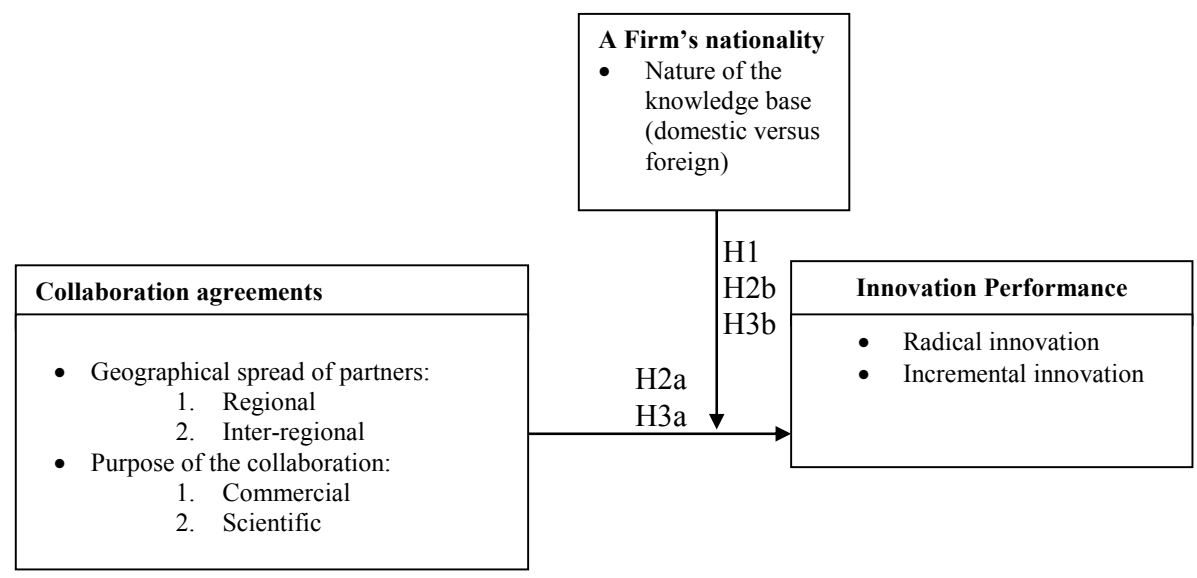

\section{Theorizing collaboration patterns}

Traditional literature has been largely concerned about external knowledge and innovation, devoting particular attention to performance issues. In today's knowledge-based economy, the ability to innovate is more important than cost efficiency in determining firms' sustainable performance. The ability of the firm to benefit from innovations in such environments quickly erodes and firms must obtain relevant knowledge in order to develop efficient innovations. Consequently, companies must balance their capacity to develop know-how with their ability to introduce novel products.

Innovations occur as a result of interactions between various actors rather than as a result of a solitary genius (Von Hippel, 1988); therefore, we must explore how collaboration mediates on it.

Traditional literature initially examined how markets for technology would enact innovation performance (Caves, Crookell and Killing, 1983; Hennart, 1988; Williamson, 1989; Mitchell and Singh, 1992; Hagedoorn, 1993). However, more recent studies have been focused on the effect of different innovative collaboration strategies in technological evolution (Rosenkopf and Nerkar, 2001), and the implications of an innovation search strategy on the final product introduction (Ahuja, 2000; Chesbrough, 2003; Laursen and Salter, 2006; Alcalde 2014). Another stream of research focuses on the motivation behind the type of collaboration and its impact on innovation performance (Miotti and Sachwald, 2003; Becker and Dietz, 2004); Belderbos et al., 2004; Nieto and Santamaría, 2007; Tsai and Wang, 2009).

However, the willingness to engage in collaborative agreements is conditioned by the internal organizational ability to explore the external 
environment. Thus, the knowledge base of the company defined by a firm's nationality will be crucial to understanding the firm's strategic behaviour and innovative performance in international markets. Previous literature is equivocal about the innovativeness efficiency of domestic versus foreign companies.

Researchers conclude that the final impact of external knowledge acquisition on performance depends on many elements: theoretical assumptions; context; specifics of knowledge and its sources; type of innovation; and type of performance variable analyzed (Frenz and lettoGillies, 2009).

On one hand, one literature stream argues that foreign firms face home country knowledge restrictions; therefore, these companies suffer a pervasive dependency on home country sources as a main driver of innovation. Research posits that foreign firms provide important vehicles for transferring research and knowledge within MNE units while external collaboration can lead to a depreciation of internal capabilities and coordination costs (Weigelt and Sarkar, 2009).

Another literature stream considers external knowledge as a means to foster innovation by getting access to specialized resources and learning opportunities from the host country. More specifically, external knowledge flows have a positive impact on firm performance both through their direct effect on innovation by the subsidiary and, indirectly, through stimulating knowledge flows between the subsidiaries and other units within the MNE (Yasmin and Otto, 2004).

In the same way, research shows evidence that foreign firms use host knowledge to a greater extent than similar domestic firms (Almeida, 1996) and are most likely to result in innovation (Almeida and Phene, 2004, 2008).

These debates on the development of efficient collaborative agreements, a firm's nationality and innovative performance supports this paper to explore how foreign-domestic firms differ in product innovation novelty through technological collaboration practices in the Basque Country. To accomplish this research question, we addressed the following issues: the differentiation of technological collaboration strategies according to both the knowledgebased dimension and geographical location, and the empirical assessment of such collaboration strategies on different degrees of product innovation novelty (incremental and radical innovation).

\section{Hypotheses}

As pointed out before, companies must create new knowledge and renew their technological competences in order to be innovative. a firm's innovation 
strategy involves a complex decision: whether to rely on internal R\&D sources, external R\&D sources, or apply both of them.

On the one hand, reliance on internal R\&D has time and cost advantages, but over-reliance can lead to organizational rigidities and competency traps (Leonard-Barton, 1992).

On the other hand, external knowledge sourcing allows firms to explore new windows for opportunity, enlarge the innovation scope and more flexibility to face market uncertainty. Companies that achieve this flexibility are able to cope better with the speed, cost and complexity of technological development (Vanhaverbeke, Duysters, and Noordhoven, 2002; Tsai and Wang, 2009) and improve the organizational performance (Grant, 1996; Zahra and Nielson, 2002).

In the attempt to build a competitive innovation pattern, firms evaluate different partnership combinations, according to innovative purposes and firms' internal ability to profit from external linkages.

The goal of this study is to understand the rationale behind a competitive innovation pattern for companies located in the CAPV. In order to fulfill this objective from a reliable perspective, the study accounts for different technological collaboration dimensions: the geographical spread of partners with whom they cooperate (geographical location), and the purposes for which they deploy technological collaboration (knowledge-based dimension).

As long as the geographical location of partners shapes the content, the scope of the cooperative agreement and external knowledge should be analyzed according to the geography of collaboration in order to understand its effectiveness in innovation output. Specifically, this study distinguishes between different geographical levels, and regional and inter-regional technological collaborations. On the other side, external sources involve linkages with different organizations such as: corporate groups, customers, suppliers, competitors, consultants, technological centers, laboratories, universities and government agencies. Thus, this organizational heterogeneity must be analyzed carefully to understand its implications in the innovation output, making it essential to analyzing the purpose for which they deploy technological collaboration. This study follows (Yamin and Otto 2004) and distinguishes between business and non-business linkages. Specifically, this study differentiates between science-based and commercial-based technological collaborations. While commercial-based partners are located across the value chain and expected to be more directly related to problem-solving, science-based linkages may be more exploratory in nature. Thus, the impact of science system collaboration may help firms to redirect their efforts towards innovation sources. However, commercial-based agents would help firms to exploit their current knowledge patterns and search for new product solutions. 


\section{Foreign-domestic firms collaboration and product innovation}

In order to determine how domestic firms could increase their innovation competitiveness in the market, this study explores if a firm's nationality moderates its ability to exploit collaboration agreements and its impact on product innovation.

As pointed out in the literature, technological collaboration practices are an important source of competitive advantage. Access to external relevant sources allows organizations to obtain relevant knowledge which cannot be produced inside the organization. Collaboration networks would support the innovation activities of collaboration partners, increasing the ability to introduce new products (Nieto and Santamaria, 2007; Becker and Dietz, 2004). Firms will consider external partners as sources of valuable knowledge, which cannot be produced internally, maximizing firm value through partners' resources combination and complementarities exploitation (Kogut, 1988).

However, the success of collaboration is conditioned by internal organizational characteristics and the willingness to engage in different collaborative agreements. In this sense, the latent nature of firms' knowledge base defined by nationality will be crucial to understanding their collaboration path and product innovation.

The starting point of this research analyzes if a firm's nationality moderates the impact of technological collaboration agreements on product innovation novelty.

The Basque Country is an example of sustainable regional development (Orkestra, 2008; OECD, 2011) and is the result of an effective cluster policy. The knowledge base in cluster emerges on the basis of technological complementarities (Porter 2003), claiming that specialization of related industries is beneficial for regional development (Boschma, Minondo and Navarro, 2010). This knowledge is supported by the dynamic flow of industryrelated information, and the involvement of local culture with specific norms values and institutions (Malmberg and Maskell, 2002). This particular specialization from the knowledge base affects what is done within and among the firms and therefore what is learnt, how things are done and consequently how learning takes place (Lundvall and Maskell, 2000). According to previous assumptions, cluster industries would support an intensive collaboration among firms to benefit from specialized local synergies (Maskell, 2001); this restrictive collaboration will constrain the benefits from a broader collaboration strategy.

On the other hand, foreign firms own an international knowledge base from international market and heterogeneous partners. The subsidiaries of multinational corporations (MNC) have the potential to develop their knowledge base from two distinct knowledge contexts. As Almeida and 
Phene (2004) posited: "First, subsidiaries are, a part of a MNC that has the capacity to share knowledge across its various units (Bartlett and Ghoshal, 1989). Second, subsidiaries are located in host country regions that often embody social, professional, and technological relationships among firms permitting inter-firm knowledge flows". The ability to develop technological agreements through these two different contexts would have a positive effect in innovation achievement (Andersson and Forsgren, 2000).

From literature sources, it is well known that innovation opportunities exist because of information asymmetry, and that firms that have access to a larger variety of sources of information are in a better position to identify and develop innovation opportunities and introduce products with a higher degree of novelty (Venkataraman, 1997; Amara and Landry, 2005). Due to foreign-owned firms benefitting from subsidized and more diverse networks, they would overcome over-specialization strategies supported by Basque region clusters. It seems reasonable to hypothesize that technological collaboration strategies developed by foreign firms have a higher impact on achieving novel innovation than the collaboration of domestic firms.

H1: "Among firms competing in the CAPV, the collaboration of foreign firms has a higher positive impact on novel product innovations than the collaboration of domestic firms"

\section{Foreign-domestic firms' geographical collaboration and product innovation}

In this section, we explore how a firm's nationality moderates the impact of different types of geographical technological collaboration on product innovation novelty. Specifically we want to answer:

1) Which type of geographical partnerships have a positive impact on novel product innovation

2) In which type of geographical partnerships do foreign-owned firms achieve superior innovation performance than domestic-owned companies.

In this sense, it would be interesting to analyze if the geographical dimension of the network would dictate firms' innovation competitiveness. In this sense we distinguish between three different types of collaborations patterns: regional (within CAPV), inter-regional (outside CAPV) and diverse geographic networks (regional and inter-regional partnerships).

As long as the geographical location of the partner just focuses on the geographical location (and does not distinguish between the knowledge content of the partnership), regarding the inter-regional we could posit the 
following arguments according to the spatial collaboration typology and product innovation novelty.

First, firms located in the CAPV are involved in a localized cluster, where their knowledge base is based on specialization from related regional industries. If firms decided to support regional networks involving short distances across collaborators they would benefit from knowledge externalities: bringing people together, favoring information contacts and facilitating the exchange of tacit knowledge and innovation performance (Jaffe, Trajtenberg, Henderson, 1993; Audretsch and Feldman, 1996; Boschma, 2005). However, over-reliance on closer partners would lead to a spatial lockin. When regions become too inward looking, the learning ability of local actors may be weakened to such an extent that they lose their innovation capacity and cannot respond to new environments (Boschma, 2005).

On the other hand, inter-regional networks would imply the access to collaborators outside the CAPV and enrich their knowledge base. This collaboration would allow firms to avoid a spatial lock-in risk and encourage interactive learning. Nevertheless, an exclusive reliance on inter-regional networks will make firms loose cluster advantages from closer interactions and tacit knowledge. Firms' distance from current knowledge sources would have a negative impact on innovation performance (Jaffe et al. 1993). Therefore, inter-regional collaboration would have a positive impact on product innovation if firms had the capabilities to integrate external knowledge and share the same values and expectations with inter-regional partners.

Finally, firms located in the CAPV which develop both regional and interregional networks will have a greater positive impact on the degree of product innovations than collaboration with only one type. An exclusive regional competitive pattern leads to an emphasis on the potential advantages of close and familiar cooperative exchange and encourages an excessive knowledge specialization. Thus, supporting excessive regional external sources will allow for the emergence of "lock-in" risk that deters firms' ability to develop product innovation. However, a combination between regional and inter-regional networks will allow firms to overcome experiential learning disadvantages from unfamiliar markets and cultural barriers. Looking at a firm's nationality we can posit that diversity in geographical collaboration would benefit all firms located in the CAPV. Foreign firms would reinforce their innovation position (through both host country networks and interregional opportunities), and it would allow domestic firms to support new diversification patterns, profiting from inter-regional partners. 
H2a: "Among firms competing in the CAPV, diversity in geographical collaboration will have a more significant impact on product innovation novelty than collaboration with only one type of geographical partner"

According to the second question related to foreign firms' advantage in geographical collaboration, we posit the following reasoning.

If we look at the different geographical partnership patterns, it seems reasonable that exclusive dependence on regional networks by foreign firms will be harmful for the MNC knowledge base. More specifically, MNC's advantages due to experiential learning advantage and knowledge specificity would be lost due to exclusive reliance on regional partnerships that would involve subsidiary autonomy, which does not match with headquarter dependency. In the same way, we cannot assume the superiority of foreign firms in exploiting diverse geographical collaboration. Thus, while this diversity would benefit foreign firms in the reinforcement of their innovation position (through both host country networks and inter-regional opportunities), domestic firms would overcome lock-in risk, profiting from inter-regional and local partners.

So, the advantage for foreign firms in product innovation according to geographical collaboration would emerge from exclusive inter-regional technological collaborations. Foreign firms have easier access to these partnerships than domestic ones due to the nature of their knowledge base. More specifically, they have greater abilities to profit from inter-regional collaborations because they already benefit from current international knowledge sources, and openness culture (Ebersberger and Herstad, 2011). This knowledge orientation provides international platforms for collaboration in the form of subsidiaries abroad (Phene and Almeida, 2008) and learning advantages by identifying place-specific opportunities and partners with whom tight interaction is required (Lowe and Wrigley, 2010). On the other hand, firms in localized clusters stress informal networks and face-to-face contact to facilitate the exchange of specialized knowledge.

It can be concluded that foreign firms would benefit from easier access to international networks and experiential learning advantages to exploit inter-regional knowledge. However, domestic firms rely on relationships based on closer contact, and find it difficult to overcome experiential learning disadvantages in inter-regional contexts.

H2b: "Among firms competing in the CAPV, the inter-regional collaboration of foreign firms has a higher positive impact on novel product innovations than the inter-regional collaboration of domestic firms" 


\section{Foreign-domestic firms' knowledge-based collaboration and product innovation}

In this section, we explore the role of different types of knowledge-based technological collaboration and the effect on innovation output. Specifically, we want to answer:

1) Which type of knowledge-based partnerships have a positive impact on novel product innovation

2) In which type of knowledge-based partnerships do foreign firms achieve superior innovation performance than domestic companies.

In this hypothesis there is an analysis of whether the knowledge orientation of the collaboration differs in product novelty. We distinguish between three different types of collaborations: science-based, commercialbased and diverse knowledge-based partnerships (scientific and commercial).

Science-based partners involve research organizations that encourage collaboration based on the first stage of generic knowledge (Belderbos, Carree, Diederen, Lokshin, Veugelers, 2004), providing new scientific and technological knowledge rather than exploiting innovation investments in the short-term and final product innovation. (Lundvall,1992; Drejer and Jørgensen, 2005). An exclusive reliance on scientific collaboration would be contrary to the assumptions involved in cluster industries, which support specialized industrial knowledge bases (Malmberg and Maskell, 2002). More specifically, an over-reliance on scientific collaborations would prevent these firms benefitting from interactive learning, which requires people sharing the same knowledge base and expertise to learn from each other (Boschma, 2005). In other words, a unique reliance on scientific partnerships involves too much distance across collaborators' knowledge bases, leading to difficulties in knowledge absorption and exploitation (Cohen and Levinthal, 1990). Therefore, we can conclude that a lack of complementarities in knowledge sources would be detrimental to the development of a novel product innovation.

Commercial partnerships involve collaboration among different collaborators in the industrial value chain. These technological collaborations will look for a fast return on their investment in order to obtain product commercialization benefits and involve knowledge that often is tacit and context-specific. Thus, an exclusive technological collaboration with commercial partners would be detrimental to learning and innovation due to a lock-in risk. Innovation requires complementary but dissimilar bodies of knowledge; thus homogeneous collaborations of specific knowledge would lead to competency traps, and a lack of novel sources (Boschma, 2005). Therefore, firms will suffer from myopia by restricting their innovation output to current technological combinations and deterring further innovation. 
According to the previous argument, the unique reliance on commercial collaboration would make firms focus on incremental rather than novel innovation.

Nevertheless, Maskell (2001) posits that commercial collaborations can fulfill requirements for effective product innovation in firms in geographical clusters if it involves dissimilar and complementary knowledge leading to sustainable specialization, where the knowledge bases of the firms diverge to such an extent that interactive learning is stimulated.

However, a commercial partnership focused on specific and similar knowledge would be detrimental to innovation novelty. From this premise we cannot hypothesize either a positive or negative impact on novel product introduction; the final effect would depend on a firm's ability to encourage collaborations based on either dissimilar or traditional similar knowledge.

On the other side, diverse collaboration involves a great benefit for firms located in the CAPV, supporting new innovation patterns and encouraging novel product innovations. Diversity in technological collaborations would allow firms to benefit from scientific generic knowledge that is useful for developing new diversification patterns and avoiding lock-in risk. In the same way, commercial collaboration would allow firms to exploit their current knowledge base with different actors in the commercial value chain and the advantages of a cluster industrial network. Therefore, we can conclude that the variety of partners will have a greater positive impact on the degree of product innovation novelty than collaboration with only one type of partner (Nieto and Santamaría, 2007).

H3a: "Among firms competing in the CAPV, diversity in knowledge-based collaboration will have a more significant impact on product innovation novelty than collaboration with only one type of knowledge-based partner"

According to the second question related to foreign firms' advantage in these types of collaboration, we posit the following reasoning.

As long as both domestic and foreign firms located in the CAPV rely on specific and tacit knowledge, exclusive reliance on scientific collaboration would have a negative impact on novel product innovation. In the same manner, diversity in knowledge-based collaboration will benefit both domestic and foreign firms, allowing them to benefit from generic knowledge exploration (scientific collaboration) and specific knowledge exploitation (commercial collaboration).

However, we can expect a different impact of commercial collaboration on innovation output according to firms' nationality. As posited above, foreign firms benefit from performing in two different contexts. Thus, foreign 
firms can benefit from commercial collaborations within the corporation but also from external partners. First, headquarters encourage the transference of knowledge across affiliates through an asset exploiting strategy. Second, foreign affiliates can support an asset-seeking strategy, augmenting existing assets by absorbing and acquiring technological spillovers from specific collaborators in the host-country. Therefore, pressure from headquarters to exploit R\&D investments and firms' ability to access complementary and dissimilar knowledge would encourage firms to develop novel product innovations.

$\mathrm{H} 3 \mathrm{~b}$ : "Among firms competing in the CAPV, the commercial collaboration of foreign firms has a higher positive impact on novel product innovations than commercial collaboration of domestic firms"

\section{Data and methodology}

\section{Eustat Innovation Survey}

The analysis uses firm level data from the Euskadi Innovation Survey, collected by Eustat (the Basque Institute of Statistics) in 2010 and sampled to be representative at the regional level (Eurostat, 2006). The data is generated by a self administered survey questionnaire based on the homogenized and thoroughly tested European Community Innovation Survey (CIS). CIS data is used for generating official innovation statistics on the EU and its member countries and has been used extensively for analysis in economics (Cassiman and Veugelers, 2002; Cefis and Marsili, 2006; Czarnitzki, 2005), in management studies (Laursen and Salter, 2004, 2006; Frenz and letto-Gillies, 2009; Schmiedeberg, 2008; Grimpe and Kaiser, 2010), and in economic geography (Simmie, 2003, 2004; Ebersberger and Herstad, 2011).

The total data set contains 4,220 firms, but the empirical analysis is restricted to 1,290 firms that report information about technological collaboration agreements during the three-year reference period 2008-2010. We include innovating and non-innovating to avoid biased results (Tether, 2002; Cassiman and Veugelers, 2002). 


\subsection{Methodology}

\section{Variables}

\section{*Dependent variables}

a) Radical Innovations: describes innovations with a higher degree of novelty. It takes the value 1 when the firm declares that some percentage of total turnover in 2010 comes from new or significantly improved products that were new to the market; otherwise its value is 0 .

b) Incremental Innovations: describes innovations with lower degree of novelty. It takes the value 1 when the firm declares that some percentage of total turnover in 2010 comes from new or significantly improved products that were only new to the firm; otherwise its value is 0 .

\section{*Independent variables:}

a) Collaboration (COLLABORATION). Firms indicated whether or not they had engaged in technological collaboration agreements during the period 2008-2010. COLLABORATION

b) Nationality. We create a dummy variable (FOREIGN) indicating if the firm has a foreign company as owner ( $\geq 50 \%$ of the total stock). It takes the value of 1 if the company is owned by foreign firm; otherwise its value is 0.

c) Type of technological collaborations: geographical collaborations and knowledge-based collaborations signed during the period 2008-2010. We create six dichotomous variables to measure the effect of different types of technological partnerships. According to the localization of the collaboration we distinguish between:

1) Regional collaboration exclusively (REG). The firm only collaborates with local partners during the period 2008-2010.

2) Inter-regional collaboration exclusively (INTERREG). The firm only collaborates with partners outside the region during the period 20082010.

3) Diverse-geographical collaboration (DIVERSEREG). The firm collaborates with both regionalandinter-regional partners during the period 2008-2010. According to the knowledge-based character of the collaboration we distinguish between:

4) Science collaboration exclusively (SCIENCE). The firm only collaborates with science-based partners during the period 2008-2010. Science collaboration includes: universities, technological centers, R\&D laboratories, and government organizations (Yamin and Otto, 2004)

5) Commercial collaboration exclusively (COMMERCIAL). The firm only collaborates with commercial-based partners during the period 2008- 
2010 (Commercial collaboration includes: affiliates and subsidiaries, customers, suppliers, competitors, and consultancy firms.

6) Multi-knowledge collaboration (DIVERSEKNOW). The firm collaborates with both science and commercial partners during the period 2008-2010.

These mutually exclusive variables avoid potential problems of multicollinearity and capture the impact of each partner more clearly by separating it from the effects attributable to other partner types in heterogeneous networks (Nieto and Santamaría, 2007).

\section{* Control Variables.}

We realize that the levels of innovation in firms will depend on internal and external environmental factors regardless of collaborative agreements; therefore, we include different control variables for firm specific and industry characteristics.

According to firm specific characteristics we control for the size of the company, export intensity, group affiliation, R\&D internal intensity, knowledge protection. Firstly, several studies find that the differences between domestic and foreign firms are mainly due to the different firms' group size (Falk, 2008); therefore, we control for the logarithm of company turnover (NETSALES). EXPSHARE measures the international orientation of the firm by its export share. Company group, irrespective of the location of company subsidiaries, is positively associated with innovation performance, we use a binary variable (GROUP) coded 1 if an enterprise is part of a company, and coded 0 if it is a single-unit firm. We include an indicator for internal R\&D intensity, measured as the ratio of internal R\&D expenses to the firm's total turnover (R\&DEXP.). An indicator for formal IPR protection is introduced because protection enables the firm to protect proprietary knowledge during collaborative work and R\&D contracting (PROPAT) (Ebersberger and Herstad, 2011).

We control for industry characteristics by the introduction of 43 industry dummy variables, albeit their coefficients are omitted from our tables (INDUSTRYDUMMIES).

\section{The Model}

As both dependent variables (Radical and Incremental) are dichotomous, estimation models such as logit or probit (Greene, 2000) would normally be appropriate. However, as the error terms of the two models are likely to be correlated, an extension of probit known as bivariate probit (Greene, 2000) is usually a more appropriate estimator. The bivariate probit model has the following specification: 


$$
\begin{array}{lll}
Z_{i 1}=\beta^{\prime}{ }_{1} X_{i 1}+\varepsilon_{i 1} \text {; if } & Y_{i 1}=1 \text { if } Z_{i 1}>0, & Y_{i 1}=0 \text { if } Z_{i 1} \leq 0, \\
Z_{i 2}=\beta^{\prime}{ }_{2} X_{i 2}+\varepsilon_{i 2} ; \text { if } & V_{i 1}=1 \text { if } Z_{i 1}>0, & V_{i 2}=0 \text { if } Z_{i 2} \leq 0, \\
\left(\varepsilon_{i 1}, \varepsilon_{i 2}\right) \approx N(0,0,1,1, \rho) & &
\end{array}
$$

The bivariate probit model was estimated using the Stata 11 routine, based on the method of simulated maximum likelihood. The difference between the specifications of each model lies in the explanatory variables (collaboration, and type of network).

\section{Results}

Table 1 below gives descriptive statistics, collinearity statistics, and correlations of all variables.

Table2 presents the regression results testing our first hypotheses. The $\rho$ parameter is highly significant, this supports the choice of biprobit instead of the probit model. The Wald test also points out high significance of both

\begin{tabular}{|c|c|c|c|c|}
\hline & \multicolumn{2}{|c|}{ Model 1a } & \multicolumn{2}{|c|}{ Model 1b } \\
\hline & RADICAL & INCREMENTAL & RADICAL & INCREMENTAL \\
\hline COLLABORATION & $0.613 * * *$ & $-0.225^{*}$ & $0.534 * * *$ & $-0.247^{*}$ \\
\hline FOREIGN & $0.516^{* *}$ & -0.008 & 0.186 & -0.134 \\
\hline COLLABORATION*FOREIGN & & & $0.802 * *$ & 0.321 \\
\hline GROUP & -0.147 & -0.019 & -0.164 & -0.024 \\
\hline R\&DEXP & -0.056 & 0.009 & -0.056 & 0.009 \\
\hline PROPAT & $0.755^{* * *}$ & -0.194 & $0.762 * * *$ & -0.199 \\
\hline EXPSHARE & $0.379 *$ & $-0.613^{*}$ & $0.418^{*}$ & $-0.599 * *$ \\
\hline NETSALES & 0.013 & $0.074^{*}$ & 0.013 & $0.073 * *$ \\
\hline INDUSTRY DUMMIES & \multicolumn{4}{|c|}{ Significant } \\
\hline LR rho $=0$ & \multicolumn{2}{|c|}{39.974} & \multicolumn{2}{|c|}{40.448} \\
\hline Wald test of full Model & \multicolumn{2}{|c|}{303.98} & \multicolumn{2}{|c|}{305.35} \\
\hline Log pseudolikelihood & \multicolumn{2}{|c|}{-913.985} & \multicolumn{2}{|c|}{-910.21} \\
\hline Number of observations & \multicolumn{2}{|c|}{1290} & \multicolumn{2}{|c|}{1290} \\
\hline One-tailed $t$-test applied. & $* * * p>.01$ & $* * p>.05$ & $* p>.10$ & \\
\hline
\end{tabular}
variables for the models.

Table 2. Collaboration impact on product innovation 


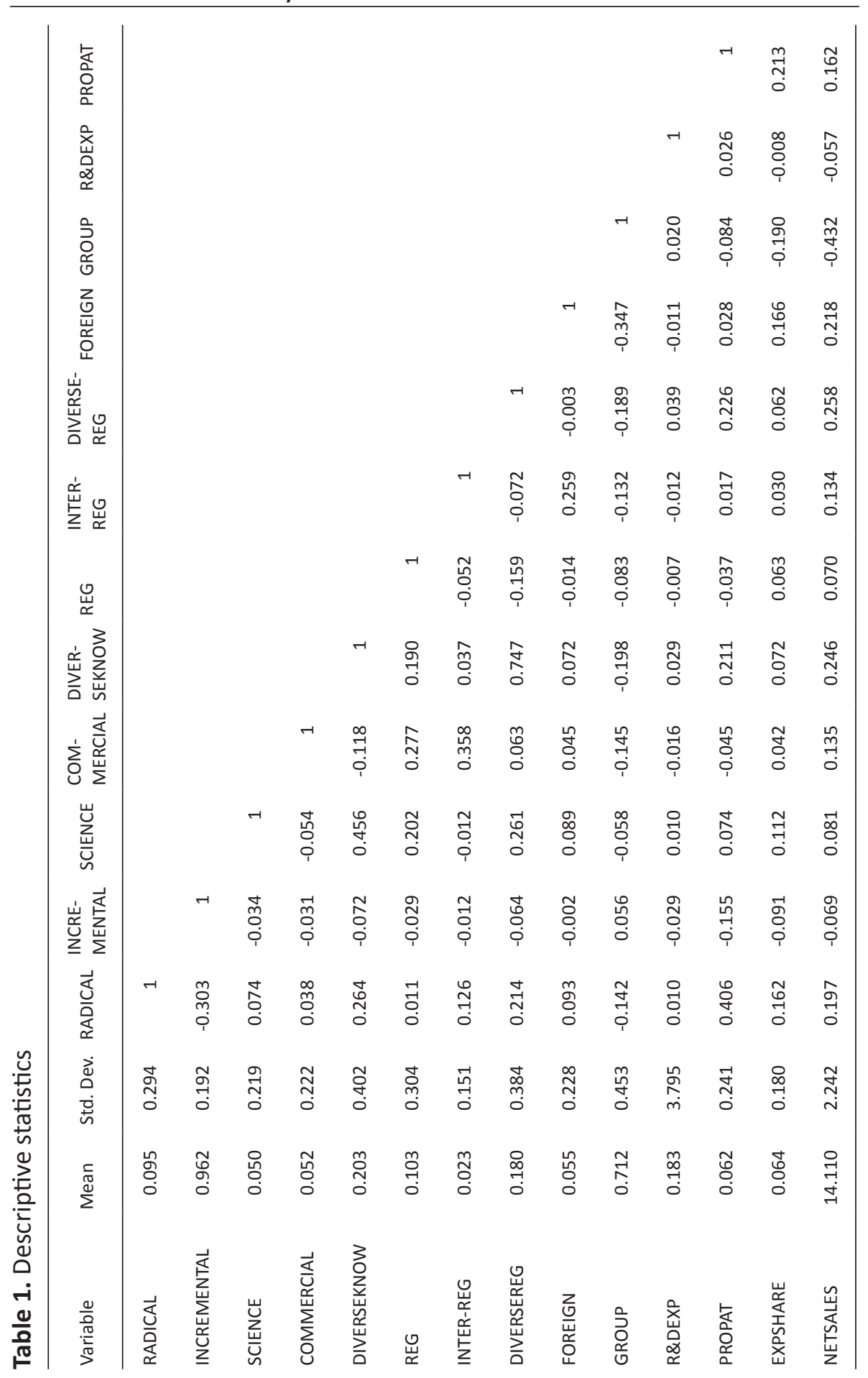


In Model 1a we test the impact of collaboration on the development of novel products. As expected, the collaboration effect is positive and significant in firms' ability to develop radical product innovations; however, collaboration has a negative and significant impact on incremental innovations. The effect of a foreign nationality is highly significant in radical innovations; however, this foreign nationality takes a negative but insignificant effect on the development of incremental innovations.

In Model $1 \mathrm{~b}$ we test Hypotheses 1 to analyze if the effect of collaboration on product innovation would be higher in foreign rather than domestic companies. We find support for our Hypothesis 1 provided that the coefficient of the interaction term between the variables. COLLABORATION*FOREIGN is positive and statistically significant in radical innovations. The impact of collaboration remains positive and significant, but the effect of the foreign nationality of the company becomes insignificant in the development of novel products. This makes us believe that foreign firms' superiority in radical innovation relies mainly on its superior ability to benefit from collaboration, rather than its international nature. According to incremental innovations, collaboration is negative and significant, while foreign nationality does not have a significant effect. Consequently, the collaboration of foreign firms does not have a higher positive impact on incremental product innovations than the collaboration of domestic firms; therefore, COLLABORATION*FOREIGN is not significant in achieving less novel innovations. The effect of the control variable PROPAT on the likelihood of achieving innovations is positive and significant in the case of radical innovations. The variable for EXPSHARE has a positive and significant effect on the development of radical innovations, while it takes a negative and significant value in incremental innovations. The size of the firm controlled by NETSALES is a positive and significant factor for the achievement of less novel innovations.

Table 3 presents the estimated results for the impact of different types of geographical collaborations on the degree of novel product innovation; and the significance of nationality in determining geographical collaboration impact on product innovation. The $\rho$ parameter is highly significant, this supports the choice of biprobit instead of the probit model. The Wald test also points out the high significance of both variables for the models.

Model 2a estimates the impact of different types of partnerships according to geographical location in firms located in the CAPV. Results suggest that the effect of collaboration depends on the type of partner. 
Table 3. Geographical collaboration impact on product innovation

\begin{tabular}{|c|c|c|c|c|}
\hline & \multicolumn{2}{|c|}{ Model 2a } & \multicolumn{2}{|c|}{ Model 2b } \\
\hline & RADICAL & INCREMENTAL & RADICAL & INCREMENTAL \\
\hline REG & $0.369 * *$ & -0.280 & $0.324 * *$ & -0.226 \\
\hline INTER-REG & $0.968 * * *$ & -0.320 & 0.507 & -0.578 \\
\hline DIVERSEREG & $0.709 * * *$ & -0.181 & $0.672 * * *$ & -0.227 \\
\hline FOREIGN & $0.174 * *$ & 0.009 & 0.181 & -0.152 \\
\hline REG*FOREIGN & & & 0.455 & -0.569 \\
\hline INTER-REG*FOREIGN & & & $1.401 * *$ & 1.029 \\
\hline DIVERSEREG*FOREIGN & & & 0.548 & 5.385 \\
\hline GROUP & -0.150 & -0.024 & -0.165 & -0.023 \\
\hline R\&DEXP & -0.054 & 0.009 & -0.055 & 0.009 \\
\hline PROPAT & $0.730 * * *$ & -0.205 & $0.732 * * *$ & -0.231 \\
\hline EXPSHARE & $0.422 *$ & $-0.620 * *$ & $0.475 * *$ & $-0.508 * *$ \\
\hline NETSALES & 0.005 & $0.072 * *$ & 0.006 & $0.074 * *$ \\
\hline INDUSTRY DUMMIES & \multicolumn{4}{|c|}{ Significant } \\
\hline LR rho $=0$ & \multicolumn{2}{|c|}{39.810} & \multicolumn{2}{|c|}{41.561} \\
\hline Wald test of full Model & \multicolumn{2}{|c|}{309.690} & \multicolumn{2}{|c|}{308.600} \\
\hline Log pseudolikelihood & \multicolumn{2}{|c|}{-910.318} & \multicolumn{2}{|c|}{-902.871} \\
\hline Number of observations & \multicolumn{2}{|c|}{1290} & \multicolumn{2}{|c|}{1290} \\
\hline
\end{tabular}

While exclusive regional collaboration (REG) has a positive and significant effect on the development of radical product innovation, exclusive interregional collaboration (INTERREG) does not have a significant impact on the achievement of novel products. As expected, diversity in geographical collaboration (DIVERSEREG) has the largest positive effect and significance in the achievement of radical innovations. Therefore, we can confirm our Hypothesis $2 a$ related to the highest significant impact of heterogeneous geographical networks in the development of new products.

Model $2 b$ estimates the impact of different geographical technological networks in product innovation according to foreign nationality. In order to analyze this issue, we create three interactions capturing the effect of different geographical networks in foreign firms: REG*FOREIGN, INTERREG*FOREIGN, DIVERSEREG*FOREIGN. The introduction of these interactions allows us to 
isolate the effect of collaboration performed by foreign firms in product innovation. Through the application of these interactions we can confirm our Hypotheses $2 \mathrm{~b}$. Foreign firms' advantage on geographical collaboration relies on inter-regional collaboration, INTERREG*FOREIGN is positive and significant in the achievement of novel products. However, foreign firms do not take a higher advantage from exclusive regional or diverse geographical networks than domestic firms, as long as REG*FOREIGN, DIVERSEREG*FOREIGN does not have a significant effect.

According to the development of incremental innovations, neither the type of geographical collaboration nor foreign-collaboration interactions have a significant impact.

The effect of control variables is similar to the previous model.

Table 4. Knowledge-based collaboration impact on product innovation

\begin{tabular}{|c|c|c|c|c|}
\hline & \multicolumn{2}{|c|}{ Model 3a } & \multicolumn{2}{|c|}{ Model 3b } \\
\hline & RADICAL & INCREMENTAL & RADICAL & INCREMENTAL \\
\hline SCIENCE & $-0.408 * *$ & 0.106 & $-0.523 * *$ & 0.046 \\
\hline COMMERCIAL & $0.389 * *$ & $-0.441 * *$ & 0.220 & $-0.478 * *$ \\
\hline DIVERSEKNOW & $0.949 * * *$ & -0.136 & $0.923 * * *$ & -0.189 \\
\hline FOREIGN & $0.526 * *$ & 0.006 & 0.261 & -0.245 \\
\hline SCIENCE*FOREIGN & & & 0.650 & 4.575 \\
\hline COMMERCIAL*FOREIGN & & & $1.540 * *$ & 0.384 \\
\hline DIVERSEKNOW*FOREIGN & & & 0.252 & 0.785 \\
\hline GROUP & -0.131 & -0.020 & -0.143 & -0.032 \\
\hline R\&DEXP & -0.044 & 0.009 & -0.046 & 0.009 \\
\hline PROPAT & $0.696^{* * *}$ & -0.230 & $0.695 * * *$ & $-0.250 *$ \\
\hline EXPSHARE & $0.472 * *$ & $-0.648 * *$ & $0.524 * *$ & $-0.605^{* *}$ \\
\hline NETSALES & 0.004 & $0.076 * *$ & 0.002 & $0.074 * *$ \\
\hline INDUSTRY DUMMIES & \multicolumn{4}{|c|}{ Significant } \\
\hline LR rho $=0$ & \multicolumn{2}{|c|}{42.350} & \multicolumn{2}{|c|}{44.354} \\
\hline Wald test of full Model & \multicolumn{2}{|c|}{321.850} & \multicolumn{2}{|c|}{324.440} \\
\hline Log pseudolikelihood & \multicolumn{2}{|c|}{-901.416} & \multicolumn{2}{|c|}{-894.226} \\
\hline Number of observations & \multicolumn{2}{|c|}{1290} & \multicolumn{2}{|c|}{1290} \\
\hline
\end{tabular}


Table 4 presents the estimated results for the impact of different types of knowledge-based networks on the degree of novel product innovation, and the significance of nationality in determining the knowledge-based collaboration impact on product innovation. The $\rho$ parameter is highly significant, supporting the choice of biprobit instead of the probit model. The Wald test also points out a high significance of both variables for the models.

Model 3a assess the impact of different types of knowledge-based technological partnerships in firms located in the CPAV. Results suggest that the effect of collaboration on novel innovation depends on the type of partner.

As posited in the theory, exclusive science collaboration (SCIENCE) has a negative and significant effect on the development of radical product innovation; while commercial collaboration (COMMERCIAL) has a positive but insignificant impact on the achievement of novel products. The largest positive effect of knowledge-based networks is found in diverse partnerships (DIVERSEKNOW), which are positive and significant in the achievement of radical innovations. Therefore, we can confirm our Hypothesis 3a related to the highest significant impact of diversity on knowledge-based networks in the development of new products.

Model $3 \mathrm{~b}$ estimates the impact of different knowledge-based networks on product innovation according to foreign nationality. In order to analyze this issue, we create three interactions capturing the effect of different knowledge-based networks in foreign-owned firms: SCIENCE*FOREIGN, COMMERCIAL*FOREIGN, DIVERSEKNOW*FOREIGN. The introduction of these interactions allows us to isolate the effect of collaboration performed by foreign firms on product innovation. Through the application of these interactions we can confirm our Hypotheses $3 \mathrm{~b}$. Foreign firms obtain greater performance than domestic firms on commercial collaboration, COMMERCIAL*FOREIGN is both positive and significant in the achievement of novel products. This result confirms previous literature about firms' commercial collaboration in spatial clusters. Malmberg (2003) pointed out the disappointing results of commercial collaborations within clusters, and the increased attention to more informal unintended interactions.

According to the development of incremental innovations, only exclusive commercial collaboration is significant, which is a negative sign. Exclusive science collaboration has a positive but insignificant effect, and diverse knowledge-based networks have a negative but significant effect. Looking at foreign firms' advantage from knowledge-based networks, any foreigncollaboration interaction has a significant impact on the achievement of incremental innovations. Once again, the effect of control variables is similar to the previous model. 


\section{Discussion and conclusions}

Economic development is connected with the generation of innovation. Collaboration has been largely considered as an important enactor of firms' innovation ability. However, relevant literature is equivocal about the impact of different type of networks on innovation output.

In this sense, firms' particular context will dictate the best collaboration pattern to achieve a higher rate of innovation novelty. This research focuses on the development of an effective collaboration pattern for firms located in the Basque Country. Traditionally the Basque Country has been considered an example of a geographical cluster. The aim of this paper is to understand why domestic firms achieve lower innovation performance than foreign firms located in the CAPV. Specifically, we assess whether the nature of the knowledge base (defined by a firm's nationality) moderates the impact of technological collaboration agreements on the degree of product newness. Therefore, we assess differences in the way these two groups of firms organize their technological collaboration practices and the comparative differences that stem from their respective practices.

This study confirms that collaboration strategies developed by foreign firms have a higher impact on achieving novel innovation (Frenz and lettoGillies, 2004). In order to explore the source of this foreign advantage, we analyze how firms benefit from different networks (according to geographical and knowledge-based dimensions). This distinction between technological networks leads us to explore traditional cluster advantages focused on geographical proximity and specialized industry collaborations.

Firstly, when we focus on technological geographical collaboration we find that diversity in the make-up of geographical networks favors innovation novelty more than collaboration with a single type of geographical partner does. This is in line with recent cluster literature focused on spatial collaboration diversity (Boschma, 2005). By considering the individual impact of each type of geographical partner, results confirm that regional partners are the single partners who have the biggest impact on the achievement of novel product innovation. This is consistent with the argument that short distances across collaborators benefit from knowledge externalities (Jaffe et al. 1993; Audretsch and Feldman, 1996; Boschma, 2005).

Looking at foreign firms' superiority in innovation performance, we find that inter-regional collaborations seem to be the key source of advantage. Being part of a MNC allows affiliates to be involved in a multinational network and develop an open-vision of spatial collaboration. Thus, foreign firms benefit from inter-regional collaborations due to their international learning ability (Phene and Almeida, 2008; Lowe and Wrigley, 2010; Ebersberger and Herstad, 2011). 
Second, knowledge-based technological collaborations may be a makeor-break decision for the success of novel innovations across firms located in the CAPV. Our results show that diversity in knowledge networks has the greatest positive effect on radical innovations. Being integrated in a diverse knowledge-based network allows firms to benefit from generic knowledge from scientific partners in order to explore new knowledge, but also from commercial collaborators exploiting current specialized knowledge.

Looking at foreign firms' superiority in innovation performance, we can confirm commercial collaborators as a source of innovation advantage. Foreign firms have a greater chance of combining dissimilar and complementary knowledge in commercial-based collaborations. Therefore, these commercial partnerships developed by foreign firms enable them to profit from a variety of specific knowledge (across MNC and the host country) with a positive impact on novel innovations creation.

We contribute to literature exploring new global dynamics of collaboration in firms located in geographical clusters. In this sense we challenge traditional cluster assumptions by estimating the impact of difference on innovation novelty. Traditional cluster literature has stressed the rigid "local" focus; however, we take a contemporary vision by integrating ownership nationality in geographical cluster research. The introduction of foreign companies in regional systems research has been neglected due to the particular attention paid to locally owned medium-sized firms, while MNC are seen as alien in the idea of a dynamic spatial cluster (Malmberg, 2003). We provide a global pattern of effective collaborations and determine the foreign firm's collaboration advantage. In this sense, firms located in the Basque Country should encourage diversity in geographical and knowledgebased networks.

This study is a novel empirical study in the cluster theory, traditionally focused on the development of case-studies. Malmberg (2003) already suggested the importance of assessing the implications of global and local circuits in an empirical way.

Our findings provide useful managerial implications. Managers should be aware of the importance of parent choice and the diversity of collaboration strategy in order to achieve sustainable innovation. Furthermore, managers should look at gaining advantage from inter-regional and commercial partnerships in order to gain competitiveness from foreign firms. As pointed out above, radical innovation is essential for organizational competitiveness.

From the point of view of policy-makers, its mission is essential in promoting efficient practices. As long as the Basque Country is the result of an efficient regional policy, regional policy-makers should encourage a sustainable innovation strategy. In this sense, they should encourage 
science organizations to develop generic knowledge closer to domestic firms' background to motivate innovation development. In the same way, regional government should explore the rationale behind informal commercial transactions in order to promote a commercial collaboration efficient pattern. According to geographical collaboration, inter-regional partnerships should be supported, allowing firms to develop an open geographical perspective.

Finally, this work is not free from limitations. It would be interesting to enlarge empirical analysis through a larger sample from different periods. Due to data availability we have focused the analysis on product innovation, but it would be interesting to replicate this study regarding other types of innovation (process, organizational, commercial) and extrapolate global conclusions. The results warrant further study of geographical and knowledge-based networks at different levels and analyze its implications in innovation performance. Related to the empirical validation of the model, our findings could be supported by the development of an in-depth case study. Finally, although radical innovation is the most powerful source of innovation performance, we cannot underestimate the role of incremental innovation, as long as this is the dominant form of innovation. Moreover, the diffusion of radical innovations nearly always depends on incremental improvements, refinements and modifications, the development of complementary technologies, and organizational change and social learning. In the same way, the contributions of incremental innovations to address socioeconomic challenges are substantial and may be even more important in a development context. Therefore, it would be interesting to go further on the implications of different collaboration agreements on different degrees of incremental innovation.

\section{References}

Ahuja, G. (2000). Collaboration networks, structural holes and innovation: a longitudinal study. Administrative Science Quarterly, 45, 425-455.

Alcalde, M. D. H. (2014). Building product diversification through contractual R\&D agreements. R\&D Management, 44(4), 384-397.

Almeida, P., Phene, A. (2004). Subsidiaries and knowledge creation: the influence of the MNC and host country on innovation. Strategic Management Journal, 25, 847-864.

Almeida, P. (1996). Knowledge sourcing by foreign multinationals: Patent citation analysis in the US semiconductor industry. Strategic Management Journal, 17 (Winter Special

Issue): 155-165. 
Amara, N., Landry, R. (2005). Sources of information as determinants of novelty of innovation in manufacturing firms: evidence from the 1999 statistics Canada innovation survey. Technovation, 25, 245-259.

Andersson U, Forsgren M. (2000). In search of centers of excellence: network embeddedness and subsidiary roles in multinational corporations. Management International Review, 40(4), 329-338.

Audretsch, D. B., Feldman, M. P. (1996). Innovative clusters and the industry life cycle. Review of Industrial Organization, 11(2), 253-273.

Bartlett C, Ghoshal S. (1989). Managing across borders: the transnational solution. Harvard Business School Press: Boston, MA.

Becker, W., Dietz, J. (2004). R\&D co-operation and innovation activities of firms-evidence for the German manufacturing industry. Research Policy, 33, 209-223.

Belderbos, R., Carree, M., Diederen, B., Lokshin, B., Veugelers, R. (2004). Heterogeneity in R\&D co-operation strategies. International Journal of Industrial Organization, 22, 1237-1263.

Boschma, R.A. (2005). Proximity and innovation. a critical assessment. Regional Studies, 39(1),

61-74.

Boschma, R.A., Minondo, A., Navarro, M. (2010). Related variety and regional growth in Spain.

Papers in Evolutionary Economic Geography 10.12, Utrecht University.

Cassiman, B., Veugelers, R. (2002). R\&D co-operation and spillovers: some empirical evidence from Belgium. The American Economic Review, 92 (4), 1169-1185.

Caves, R. E., Crookell, H., Killing, J. P. (1983). The imperfect market for technology licenses. Oxford Bulletin of Economics and Statistics, 45, 249-267

Cefis, E., Marsili, O. (2006). Survivor: the role of innovation in firm's survival. Research

Policy, 35, 626-41.

Chesbrough H. (2003). Open Innovation. Harvard University Press: Cambridge, MA.

Cohen, W.M., Levinthal, D.A. (1990). Absorptive capacity: a new perspective of learning and innovation. Administrative Science Quarterly, 35 (1), 128-152.

Czarnitzki, D. (2005). The extent and evolution of productivity deficiency in Eastern Germany. Journal of Productivity Analysis, 24, 211-231.

Drejer, I., Jørgensen, B.H. (2005). The dynamic creation of knowledge: analysing public-private collaborations. Technovation, 25, 83-94.

Ebersberger, B., Herstad, S. (2011). Go abroad or have strangers visit? On organizational search spaces and local linkages. Journal of Economic Geography, 1-23. 
Falk, M. (2008). Effects of foreign ownership on innovation activities: empirical evidence for twelve European countries. National Institute Economic Review, 204(1), 85-97.

Frenz, M., letto-Gillies, G.(2009). The impact on innovation performance of different sources of knowledge: Evidence from the UK Community Innovation Survey. Research Policy, 38, 1125-1135.

Grant, R.M. (1996). Towards a knowledge-based theory of the firm. Strategic Management

Journal, 17 (Winter Special Issue), 109-122.

Greene WH. (2000). Econometric Analysis (4th edn).Prentice-Hall: Upper Saddle River, NJ.

Grimpe, C., Kaiser, U. (2010). Balancing internal and external knowledge acquisition: The gains and pains from R\&D outsourcing. Journal of Management Studies, 47, 1483-1509.

Hagedoorn, J. (1993). Understanding the rationale of strategic technology partnering:

interorganisational modes of co-operation and sectoral differences. Strategic Management Journal, 14, 371-385.

Hennart, J.F. (1988). a transaction cost theory of equity joint ventures. Strategic Management Journal, 9 (4), 361-374.

Jaffe, A.B.,Trajtenberg M., Henderson R. (1993). Geographic localization of knowledge spillovers as evidenced by patent citations. Quarterly Journal of Economics, 108, 577-598.

Kogut, B. (1988). Joint Ventures: Theoretical and empirical perspectives. Strategic Management Journal, 9, 312-332.

Laursen, K., Salter, A. (2006). Open for innovation: the role of openness in explaining innovation performance among UK manufacturing firms. Strategic Management Journal, 27 (2), 131-150.

Leonard-Barton, D. (1992). Core capabilities and core rigidities: a paradox in managing new product development. Strategic Management Journal (Summer Special Issue), 13, 111-125.

Lowe, M., Wrigley, N. (2010). The "Continuously Morphing" retail TNC during market entry:

interpreting Tesco's expansion into the United States. Economic Geography, $86381-408$.

Lundvall, B.D., Maskell, P. (2000). Nation states and economic development from national systems of production to national systems of knowledge creation and learning. The Oxford Handbook of Economic Geography Eds G.L., Clark, M. P., Feldmann, M.S., Gertler. Oxford: Oxford University Press, 353-372.

Malmberg, A. (2003). Beyond the cluster: local milieus and global connections. In: Peck, J. and Yeung, H. W.-c. (Eds.): Remaking the global economy. London: Sage.

Malmberg, A., Maskell, P. (2002). The elusive concept of localization economies: towards a 
knowledge-based theory of spatial clustering. Environment and Planning, 34, 429-449.

Maskell, P. (2001). The firm in economic geography. Economic Geography, 77(4), 329-344.

Miotti, L., Sachwald, F. (2003). Co-operative R\&D: Why and with whom? An integrated framework of analysis. Research Policy, 32, 1481-1499.

Mitchell W, Singh K. (1992). Incumbents' use of pre-entry alliances before expansion into new technical subfields of an industry. Journal of Economic Behavior and Organization, 18(3), 347-372.

Nieto, M.J., Santamaría, L. (2007). The importance of diverse collaborative networks for the novelty of product innovation. Technovation, 27, 367377.

OECD (2011). 2011. OECD Reviews of Regional Innovation: Basque Country, Spain. Paris: OECD.

Orkestra (2008). 2008. Informe de competitividad del País Vasco. Hacia una propuesta única de valor. Bilbao: Publicaciones de la Universidad de Deusto.

Phene, A., Almeida, P. (2008). Innovation in multinational subsidiaries: The role of knowledge assimilation and subsidiary capabilities. Journal of International Business Studies, 39(5),

901-919.

Porter, M. E. (2003). The economic performance of regions, Regional Studies, 37 (6/7), 549-578.

Rosenkopf L, Nerkar A. (2001). Beyond local research: boundary-spanning, exploration, and impact on the optical disk industry. Strategic Management Journal, 22(4): 287-306.

Schmiedeberg, C. (2008). Complementarities of innovation activities: An empirical analysis of the German manufacturing sector. Research Policy, 37: 1492-1503.

Simmie, J. (2003). Innovation and urban regions as national and international nodes for the transfer and sharing of knowledge. Regional Studies, 37, 607-620.

Simmie, J. (2004). Innovation and clustering in the globalised international economy. Urban

Studies, 41, 1095-1112.

Tether, B. (2002). Who co-operates for innovation, and why. An empirical analysis. Research Policy, 31, 947-967.

Tsai, K.H., Wang, J.C. (2009). External technology sourcing and innovation performance in LMT sectors: An analysis based on the Taiwanese Technological Innovation Survey. Research Policy, 38, 518-526.

Vanhaverbeke W, Duysters G, Noorderhaven N. (2002). External technology sourcing through alliances or acquisitions: an analysis of the applicationspecific integrated circuits industry. Organization Science, 13(6), 714-733 
Venkataraman, S. (1997). The distinctive domain of entrepreneurship research. In: Katz, J., Brokhaus, R. (Eds.), Advances in Entrepreneurship. Firm Emergence, and Growth, JAI Press, San Francisco, CA.

Von Hippel, E. (1988). Sources of Innovation. Oxford University Press, Oxford. Weigelt, C., Sarkar, M. (2009). Learning from supply-side agents: The impact of technology

solution providers' experiential diversity on clients' innovation adoption. Academy of Management Journal, 52 (1), 37-60.

Williamson, O.E. (1989). Transaction cost economics. In: Schmalensee, R.Willig, R.D. (Eds.), Handbook of Industrial Organization. North- Holland, Amsterdam, 135-182.

Yamin, M., Otto J. (2004). Patterns of knowledge flows and MNE innovative performance. Journal of International Management, 10, 239- 258.

Zahra, S. A., Nielsen, A. P. (2002). Sources of capabilities, integration and technology commercialization. Strategic Management Journal, 23, 377398.

\section{Biographical Note}

Henar Alcalde Heras holds Doctorate in Business Administration and Quantitative Methods (European Mention) from the University of Carlos III, Madrid. Part of doctoral studies she conducted at the Copenhagen Business School in the Department of Innovation and Organizational Economics (INO). Since 2011 she acts as researcher at Orkestra-Basque Institute of Competitiveness, and teaches at Deusto University Strategy Deparment. Previously she has been teaching in the Business Economics Department at the University of Carlos III, Madrid. Her principal areas of interest are subjects relating to Open Innovation Strategy. In particular, the analysis of collaboration between different agents, knowledge management, technology transfer and the final impact on the results for innovation achieved by the company.

\section{Abstrakt (in Polish)}

Zdolność do tworzenia innowacji uznawana jest w coraz większym stopniu za czynnik wyjaśniający konkurencyjność przedsiębiorstw w długim okresie. w konsekwencji wzrasta znaczenie czynników decydujqcych o powstawaniu przełomowych innowacji produktu. w artykule, na podstawie zestawu wskaźników konkurencyjności, bada się wyniki osiagane przez firmy lokalne i zagraniczne w Kraju Basków, wskutek stosowania przez nie określonych metod wspótpracy w dziedzinie technologii. $w$ badaniu dq̨ży się w szczególności do określenia różnic w zakresie sposobów organizowania przez te dwie grupy przedsiębiorstw technologicznej współpracy (tj. geograficznego pochodzenia partnerów oraz celów tej współpracy: komercyjnych lub naukowych i nakierowanych na generowanie wiedzy) oraz różnic w zakresie rezultatów tych praktyk. w studium wykorzystano dane z sondażu działalności innowacyjnej przedsiębiorstw w kraju Basków w 2011 roku. w wyniku badań stwierdzono, że (a) technologiczna wspótpraca, 
która angażuje zróżnicowane grupy partnerów ma największy pozytywny wpływ na poziom nowatorstwa innowacji, oraz (b) biorqc pod uwagę narodowość firm, strategie współpracy rozwijane przez firmy zagraniczne majq większy wpływ na osiqganie nowatorskich rozwiqzań. Można przyjqć założenie, że wyższy poziom innowacyjności charakteryzujqcy firmy zagraniczne w kraju Basków w relacji do firm lokalnych, wynika ze zdolności firm zagranicznych do wykorzystywania $w$ rozwoju innowacji zarówno partnerstwa wewnq̨trz regionu, jak i powiq̨ań międzyregionalnych i sieci biznesowych.

Słowa klucze: współpraca, nowość produktu, narodowość własności, innowacja 